\title{
GUEST EDITORS' NOTE
}

\section{What new developments related to assistance are on the historiographical horizon?}

Since the late eighteenth century, assistance institutions have been an important source of support for government policies, and organized themselves from more general discussions on philanthropy, a concept which brought together seemingly disparate issues such as the abolition of slavery, the medicalization of hospitals, work regimes, the evils of poverty, civility, and hygienism, among many others. Philanthropists proposed the reform of "society" and advocated solutions for abandoned children, hospitals for the poor, freedom for slaves, education for workers, dignity for prisoners, extension of health policies etc.

It was from this broad repertoire that policies for organizing assistance were formulated, granting a global relevance to the local solutions which were proposed at different points in Brazil. These multiple meanings permitted prescriptions broad enough to establish a type of common heritage of civility and progress, but which also at the same time needed to be organized according to "national" issues (such as slavery and its consequences, for example) to formulate policies related to care for poor workers. The network of hospitals that arose in the interior of Brazil did not have a minimum standard of services, but pragmatically took advantage of a general sense of philanthropy understood in very generic terms as "love for humanity."

While the states were effectively key actors which replaced charity with notions of civility and citizenship, the model based on elite participation in line with new meanings for this activity (without removing the old religious implications) remained personalistic and localist, decrying the intimate relationship between the state and grassroots-level entities that gave rise to assistance activities. The formulation of "public" policies carried out by individuals and/or private institutions was key in understanding the origin and structuring of political powers nationally as well as locally. In this sense, any mechanical separation between delay and progress labels assistance as an intransigent archaism and proves damaging.

The challenge is to understand the success of traditional institutions which were also the main vectors of scientific thought and the reinvention of modern assistance. But this does not entail creating an "origin myth" for assistance establishments, which would inexorably bring welfare back to the government, as an idea devoid of all the personalism of the old models. It is important to understand how the values and actions that drove social groups were historically targeted within the logic that affected them. Despite the apparent "modernity" of philanthropy, assistance institutions for the most part remained 
within the same organizational patterns, restricted to the "charitable" elites who justified their activities as an exercise of compassion (moral and/or civic) in the face of social ills. Until the 1930s, the assistance network - whether inspired by religion or civic duty - was mostly centered around local elites working closely with the government.

A significant historiographic change can be seen in research on assistance: the memory produced by these establishments often does not correspond with what can be found in the archives, since charity, philanthropy, and even citizenship are not static concepts, but rather result from disputes that limit the range of specific activities. Charity, philanthropy, and citizenship are not timeless abstractions that hover above political organizations, but instead are the fruit of controversies that grant them scope and emphasis, historically incarnating them into laws, institutions, and state policies. In this sense, motives for assistance cannot be strictly delineated, defining specific steps and logic a priori that could shape activities by charitable organizations in a defined manner. In short, the ways by which modern assistance policies are directed originate (in various ways) from centuries-old discussions.

\section{The emblematic Misericórdia Brotherhood: memory, historiography, and challenges}

Although assistance is organized through a broad range of institutions, the Portuguese and Brazilian historiography has focused on the Santa Casa da Misericórdia Brotherhood. From the outset, we warn the reader that our goal is not to discuss the recent historiography on this topic (even though pioneering studies do appear in our narrative), but rather to point out challenges that may be useful for new investigations.

During the last decades of the twentieth century, studies on the poor, poverty, charity, assistance, and public policies have multiplied, particularly with the advent of the Annales school of historiography which permitted dialog between history and the other humanities and social sciences. The work of Michel Foucault (1987) gave rise to a line of interpretation focused on the mechanisms of social control and discipline that characterized policies for assisting the poor. Studies by Bronislaw Gemerek (1995) and Robert Castel (2015) also created an analytical bias by establishing a relationship between economic transformations and public policies adopted within certain historical contexts. Finally, other historiographic approaches have also emerged that discuss public and private assistance, establishing links between the two.

The poor and the control of poverty became a topic of study, particularly from the nineteenth century on, when growing industrialization and development of capitalism exacerbated social inequalities, instead of solving them as expected. One reference from this period is Alexis de Toqueville's 1833 Memoir on pauperism (2003), which looked for the historical causes of poverty and indigence, comparing living conditions in countries with different levels of socioeconomic development.

In Brazilian history, it was some time before the place of assistance institutions (particularly the misericórdias) was analyzed systematically. For this reason, until the 1960s the history of the misericórdias was written by the charity institutions themselves and seen by "professional" history as overly religious and invariably apologetic. Varnhagen (1854), in the founding work of Brazilian historiography, makes a brief reference to the 
misericórdias here between the sixteenth and seventeenth centuries. The backdrop for the history of assistance has changed as postgraduate programs emerged and more contacts were made with international historiography. Work by the British diplomat Charles Boxer (1904-2000) was fundamental in underscoring the irrefutable importance of the Santas Casas de Misericórdia in overseas expansion. Not only charity establishments, these institutions were also spaces for the exercise of political power, essential in the process of westernizing the colonial regions, because together with the other religious brotherhoods they successfully formed a common cultural ground that ensured an identity for Portugal's overseas territories. As mentioned in Salvador de Sá e a luta pelo Brasil e Angola, 1602-1686 (Boxer, 1984) [Salvador de Sá and the struggle for Brazil and Angola, 1602-1686], this author's summary became a chapter in the 1969 book O império marítimo português [Portuguese seaborne Empire], in which Boxer (2002) sees the municipal councils and the misericórdias as twin pillars of Portuguese society, from Maranhão to Macao, since they promoted a degree of continuity that neither regional or church authorities were able to guarantee on their own. In the late 1990s, amid many events celebrating Portuguese discoveries, Boxer's work seemed more current than ever, and the misericórdias were unequaled as providers of institutional charity.

From this renewed imperial perspective came the 1968 text Fidalgos e filantropos: a Santa Casa de Misericórdia da Bahia, 1550-1755 [Fidalgos and philanthropists: the Santa Casa da Misericórdia of Bahia, 1550-1755] by A.J.R. Russell-Wood, one of Boxer's disciples. This book was a historiographical novelty even for Portugal, advancing Boxer's thoughts about the overseas importance of the misericórdias. Even today it is still the most complete summary of the Bahian institution, and definitively demonstrated the importance of studying not only the political aspect of the misericórdias, but also their social and religious significance within their own communities.

Although the first Brazilian edition of Russell-Wood's text was only published in 1981, the influence of Boxer and Russell-Wood was felt in Laima Mesgravis's doctoral dissertation, $A$ Santa Casa de Misericórdia de São Paulo (1599-1884), which she defended at the Universidade de São Paulo's History Department in 1973. The work of Mesgravis (1976) expressed an underlying problem: the Misericórdia in São Paulo was located in a much less economically dynamic region than Salvador, and had significantly less institutional importance than its equivalent in Bahia. It did not house orphans, support endangered children, or have a large-scale hospital until Independence. Furthermore, the documentary resources of the Misericórdia of São Paulo were limited to the colonial period.

In 1984, Caio Boschi conducted an exhaustive study on monastic life in Minas Gerais during the eighteenth century as part of his doctoral thesis, with a markedly Marxist analysis concentrated on the political importance of the brotherhoods and their role as a "supposed" arm of the Portuguese State in the captaincy. Surprisingly, even though everything appeared to contribute to the emergence of thriving misericórdias, there was not a single successful example of these institutions in Minas Gerais during the eighteenth century.

Considering the unquestionable success of the misericórdias elsewhere and their failure in Minas Gerais, Boschi (1984) arrived at a somewhat surprising hypothesis. In "O assistencialismo na capitania do ouro" ["Assistentialism in the golden captaincy"] published in 
USP's Revista de História, he suggests that the failure of these institutions in Minas developed a type of "individualist" and "egocentric" mentality, a selfish "Minas mentality" that seemed to ignore all the examples to the contrary seen in the importance of the other brotherhoods.

While Boschi's article is notable for (among other merits) drawing attention to the systemic failure of the misercórdias in Minas Gerais, he completely disregards any possibility that aid to the needy might not have passed through these institutions. To a certain extent, he links the absence of the santas casas to the impiety of the population (just as the memoirists did). Neither the minimal services offered by the misericordias nor increased provision of aid implied compassion from the monastics. And yet, to show just one example, wills from Minas Gerais are full of acts to aid the poor.

The absence of such a paradigmatic institution certainly cast a more pragmatic light on the ideal of compassion, carried out according to the donors' wishes but firmly anchored in a common discourse of charity. Even where the Misericórdias managed large estates and provided services to the community, the general notion of mercy was subject to a series of prohibitions, revealing a universalizing ideal and a discretionary practice. Especially in the case of the colonies, beneficiaries were often selected before services could be provided, and in several cases whites, Catholics, and longstanding Christians were selected as priorities beforehand.

In this respect, we should call attention to an aspect which has been absolutely disregarded by a good part of Brazilian historiography: although assistance institutions were understood to be charity establishments and urged the universal practice of this virtue, those who received the services provided by these brotherhoods often comprised a very small and not particularly representative sample of "poverty." In other words, we must constantly be alert to the fact that charity establishments selected only a minute portion of beneficiaries from large numbers of needy people. Although the institutions were very effective in producing a uniform memory of charitable organizations, the service was discretionary and often subsidized, such as in the case of the military, for example.

Starting in the late 1980s, the historiography of the Portuguese misericórdias underwent considerable renewal, starting with the pioneering work by Laurinda Abreu (1999) on the Santa Casa of Setúbal, creating a space for researchers such as Isabel dos Guimarães Sá, Maria Antónia Lopes, Marta Lobo, and many others afterward who we do not have space to mention in this slightly iconoclastic introductory letter. Between us, the work of Isabel dos Guimarães Sá (1997) was particularly important for addressing overseas regions. The text Quando o rico se faz pobre was published in the late 1990s and extended the imperial model of expansion for the misericórdias to its end, in the wake of Boxer's suggestions and the historiographical renewal that proposed an anthropological history of power.

At the beginning of the twenty-first century, following the five hundredth anniversary of the founding of the first misericórdia, the santas casas were again celebrated as a great institution which was successful throughout the empire, this time by professional historians. Portugal's colonies in the Americas seemed to be a thorn in the side of this triumphalist interpretation; one the other hand, there was no doubt that the idea of a selfish mentality was unconvincing, Instead, it is argued that the misericórdias, anywhere in the empire, should be understood in a more general light. 
Finally, another aspect directly connected to the particular nature of the public should be remembered. This is a space in which the slavery (of Africans as well as indigenous people) was undeniably important, but slaves were not among the group of poor people initially served by the misericórdias. Especially after the eighteenth century, institutional aid to mixed-race people was becoming a problem, for example in universal care for endangered children. Domestic sovereignty over slaves implied providing health care, and from the second half of the eighteenth century a series of special wards emerged on the plantations. In the cities, where the misericórdias functioned, owners of more than two slaves were expected to pay for medical care.

This aspect may have limited the misericórdias as paradigmatic institutions, because the benefiting public was reduced. But if this hypothesis is correct, the historiography cannot ignore 1888 as a key date for effective delineation in the history of assistance institutions.

Starting from the nineteenth century, the misericórdias were funded more regularly, after a period when few new institutions appeared. However, they moved farther and farther apart from the selective brotherhoods that they represented in the seventeenth century. The differentiation between nobles and artisans was abandoned in the statutes of Itu, Sorocaba, and São João del Rei, opening the brotherhood to those who were considered wealthy. There is no doubt that these institutions continued to be fundamentally important as the main providers of assistance throughout that new century. All the brotherhoods which were modestly founded in the eighteenth century became misericordias in the nineteenth century, indicating an almost "natural" trajectory for these establishments that established themselves locally.

The diversification of the main agents ran parallel to the complexification of the elites themselves, but even organized according to other parameters, the misericórdias maintained great symbolic importance and the rhetoric that loving one's neighbor was an imperative to be put into practice. This reiterated the fiction of charity which legitimized the main players in each location as they adapted to the new social configurations of that time. The brotherhoods of the misericórdias, which usually appear in the Brazilian historiography as a uniform body and natural provider of assistance work, were absolutely distinct from each other. On the eve of Independence, the solutions to poverty could be described as very Brazilian: highly customized and invariably fragmented.

The forms of assistance found by those who lived in the Portuguese Americas, a region marked by few institutions where more verticalized charity practices converged, still remain completely unknown. More research is needed in the archives of the city governments, wills, in other associations, and in faith-based organizations. The mutual model of charity was an inescapable aspect of how these societies viewed themselves, and we consequently end this letter with an invitation to everyone: Let's get to work!

\section{REFERENCES}

ABREU, Laurinda.

Memórias da alma e do corpo: a Misericórdia de Setúbal na modernidade. Viseu: Palimage. 1999.

BOSCHI, Caio César.

O assistencialismo na capitania do ouro. Revista de História, n.116, p.25-41. 1984. 
BOXER, Charles R.

O império marítimo português (1415-1825). São Paulo: Companhia das Letras. 2002.

BOXER, Charles R.

Salvador de Sá e a luta pelo Brasil e Angola 1602-1686. Rio de Janeiro: IHGB. 1984.

CASTEL, Robert.

As metamorfoses da questão social. Petrópolis: Vozes. 2015.

FOUCAULT, Michel.

Vigiar e punir: nascimento da prisão. Petrópolis: Vozes. 1987.

GEMEREK, Bronislaw.

A piedade e a forca: história da miséria e da caridade na Europa. Lisboa: Terramar. 1995.

MESGRAVIS, Laima.

A Santa Casa de Misericórdia de São Paulo (1599?-1884). São Paulo: Conselho Estadual de Cultura. 1976.

RUSSEL-WOOD, A.J.R.

Fidalgos e filantropos: a Santa Casa da Misericórdia da Bahia 1550-1755. Brasília: Editora Universidade de Brasília. 1968.

SÁ, Isabel Guimarães.

Quando o rico se faz pobre: Misericórdias, caridade e poder no Império Português, 1500-1800. Lisboa:

Comissão Nacional para as Comemorações dos Descobrimentos Portugueses. 1997.

TOCQUEVILLE, Alexis de.

Ensaio sobre a pobreza. Rio de Janeiro: TopBooks; UniverCidade. 2003.

VARNHAGEN, Francisco Adolfo de.

História geral do Brasil. t.1. Rio de Janeiro: E. e H. Laemmert. 1854.

Christiane Maria Cruz de Souza ${ }^{i}$

' Instituto Federal de Educação Ciência e Tecnologia da Bahia. Salvador - BA - Brazil orcid.org/0000-0001-9716-7891 chriscruzba@yahoo.com.br

\section{Maria Renilda Barreto}

ii Programa de Pós-graduação em Relações Étnico-raciais/Centro Federal de Educação Tecnológica Celso Suckow da Fonseca.

Rio de Janeiro - RJ - Brazil orcid.org/0000-0001-8648-0620 renildabarreto@hotmail.com
Renato Franco ${ }^{i i i}$

iii Programa de Pós-graduação em História/ Universidade Federal Fluminense. Niterói - RJ - Brazil orcid.org/0000-0003-2878-5412 renfranco@gmail.com

Tânia Pimenta ${ }^{i v}$ iv Casa de Oswaldo Cruz/Fiocruz. Rio de Janeiro - RJ - Brazil orcid.org/0000-0002-9042-7133 tania.pimenta@fiocruz.br 